ANNA ŚWIERCZ

Department of Environment Protection and Modeling, The Jan Kochanowski University in Kielce, Świętokrzyska 15, 25-406 Kielce, swierczag@poczta.onet.pl

\title{
REACTION OF CONIFEROUS FOREST VEGETATION TO PARTICULATE DEPOSITION UNDER ALKALINE PRESSURE
}

\begin{abstract}
The aim of this study was to determine direction, rate and character of the changes in coniferous forest communities caused by anthropogenic stress factors (alkaline emission and imission) changing with time. To fulfil this goal, we have performed comprehensive studies of soils and plants at the study sites located in coniferous forest communities remaining under direct influence of cement and lime industry in the Świętokrzyskie Voivodeship. There were differences in the accumulation of elements in pine needles collected at alkalized sites in comparison with needles from the control site: $\mathrm{Ca}$ content was 2.5 times higher and $\mathrm{Cu}, \mathrm{Pb}$ and $\mathrm{Sr}$ contents were 2-3 times higher, while $\mathrm{Al}$ and $\mathrm{Fe}$, and $\mathrm{Mn}$ contents were twice and 10 times lower respectively. SEM analysis of morphological features of pine needle surface, in particular degree of preservation of epicuticular waxes can be as an indicator of assimilatory organ degeneration caused by dust deposition which induces wax layer erosion. Declining species number and biodiversity, particularly conspicuous at the Sitkówka site, was a general tendency observed over the study period (from 18 to 10 years). Other noticeable processes include slow regenerative changes of the community with a tendency towards higher contribution of acidophilic coniferous forest species with lower light and temperature requirements and suppression of meadow, ruderal and associated taxa. Further studies are required in order to define succession rate and direction of changes in species composition of these communities.
\end{abstract}

Key words: Scotch pine forests, cement dust emission, needles, reaction 


\section{INTRODUCTION}

Air pollution caused by acid deposition and photochemical oxidizer poses a serious threat to many ecosystems. In recent years, their effect has been studied in different aspects (e.g. EAGER, AdAMS 1992; GRESZTA et al. 2002; STASZEWSKI 2004). In contrast, an impact of alkaline deposition on plant communities rarer was the focus of research. The reaction of coniferous forest stands and soils to the pollution of this type was the subject of many-year monitoring studies conducted in the Świętokrzyskie Voivodeship (ŚwIERCZ 2005a).

The aim of this study was to determine direction, rate and character of the changes in coniferous forest communities caused by anthropogenic stress factors (alkaline particulate emission and imission) changing with time. To fulfill this goal, we have performed comprehensive studies of plants at the study sites: Sitkówka (since 1989), Małogoszcz (since 1997), Ożarów (since 1998), located in coniferous forest communities remaining under direct influence of cement and lime industry in the Świętokrzyskie Voivodeship. The aim of this study was examining of the reaction of vegetation after considerable lowering the alkaline emission and the possibility of return to the composition of typical pine forest communities.

\section{MATERIAL AND METHODS}

The studies were conducted at three forest sites located in the vicinity of cement plants in Sitkówka (currently Dyckerhoff Polska Ltd.) Małogoszcz (Lafarge Cement S.A.) and Ożarów (Ożarów Group S.A.; Fig. 1). All sites were located at similar distance away from particle emission source, in pine forests of DicranoPinion alliance (degenerative forms), in fresh coniferous forest habitats. The distance of study sites from the Cement Factory (Sitkówka, Małogoszcz, Ożarów) carried out $\sim 0,5 \mathrm{~km}$ (in the direction on the wind NW-SE). 


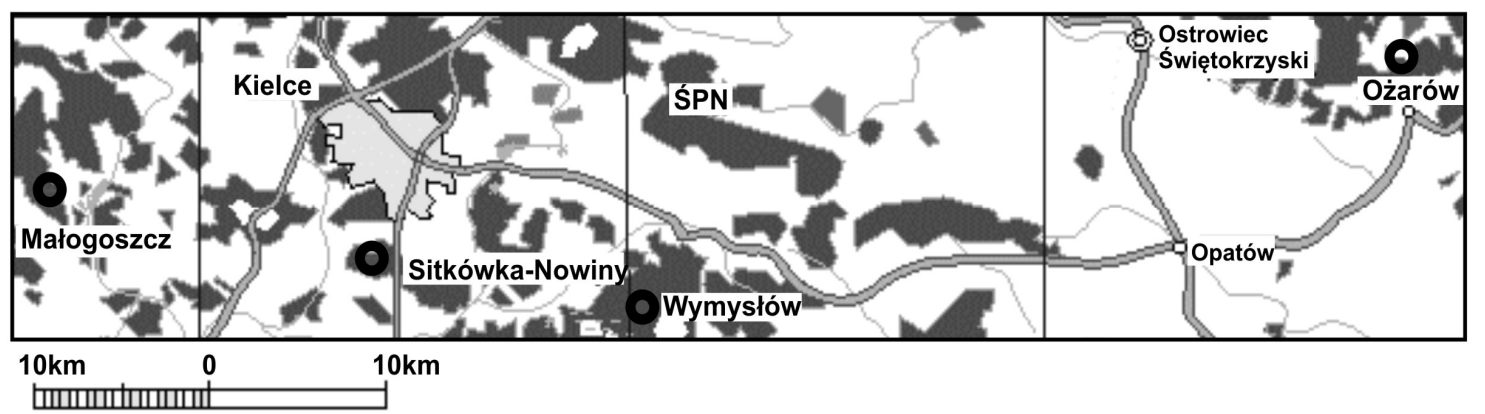

Fig.1. Location of the study sites (empty circles).

For comparison, we a site overgrown by forest of Leucobryo-Pinetum association located near the village of Wymysłów in the Cisowsko-Orłowiński Landscape Park, beyond industrial emission range (20 km from the nearest Ożarów Cement Factory). The age of trees on all investigated areas was comparable about 60 years).

At all study sites, was analysed Haplic Podzol and Albic Arenosol developed from loose to weakly clayey Pleistocene sands were identified. Phytosociological relevés were recorded and one- and two-year-old needle samples were collected. Needle samples collected from four Pinus sylvestris trees 40-70 years old were mixed for each site. The samples were dried in a dryer at $40^{\circ} \mathrm{C}$ for $24 \mathrm{~h}$, then ground in a Fritsch mill and ashed in an electrical furnace at $450^{\circ} \mathrm{C}$. Then, the samples were suspended in $\mathrm{HCl}-\mathrm{HNO}_{3}$, and total contents of selected elements were determined with ICP-AES. The state of needle surface structure was also investigated. Middle parts needles were coated in gold and photographs were taken with a JSM-5400 scanning electron microscope at magnification 2000, 1000, $500 \mathrm{x}$.

Form each of 4 surfaces 3 one-year and 3 two-year-old needles was taken for SEM examination only selected photographs of needles surfaces was presented in the paper.

Phytosociological relevés were recorded at study sites in: 1990, 2003, 2008 (Sitkówka); 1997, 2003, 2008 (Małogoszcz); 1998, 2003, 2008 (Ożarów); 1992, 2003, 2008 (Wymysłów). Quantitative changes in phytocenoses were represented by mean cover-abundance index for a species according to the formula: Iśr $=\Sigma \mathrm{p} / \mathrm{n}$, where $\mathrm{p}$ is coverage value for a given species according to a 6 point scale (from 5 to 
+ ), while $\mathrm{n}$ is the total number of releves in the table. It was decided that coverage designated by + was 0.5 in order to increase significance of sporadic species which frequently play an important role in succession. Systematic constancy of groups D (PAWŁOWSKI 1977) was calculated for the distinguished groups of syngenetic species, and mean indicator values: light (L), temperature (T), humidity (W), pH (R) and fertility - organic matter content $(\mathrm{H})$ were calculated for every community at each study site (ZARZYCKI at al. 2002). Phytosociological relevés covering about $400 \mathrm{~m}^{2}$ was performed on each of surfaces. It was redeated in the next years of investigation in the same sites.

\section{RESULTS AND DISCUSSION}

\subsection{Pine tree: wax surface structure of needles}

SEM images of pine needles collected during this study in alkalized areas and examined under 500x and 1000x magnification (Photo 1 and 2) showed a significant loss of the crystalline epicuticular wax network in comparison with needles collected in the control area (Photo 3 and 4). The surface of needles from alkalized area was classified into class III which suggests almost complete decay of wax structure in interstomatal space (according to the classification of TURUNEN et al. 1992). Deposition of dust aerosols weakened needle health status. The wax layer was discontinued, strongly eroded, locally collapsed while originally crystalline epicuticular wax became amorphic (BAČIĆ et al. 1998; STASZEWSKI 2004; ŚWIERCZ 2005a). Needles devoid of natural protection were easily attacked by filamentous fungi (Fig. 3 and 4). The degradation of needle surface wax structure influenced also their mean lifespan. It was observed that pines growing in alkalized areas shed older needles. According to the studies of MÄKELÄ and HutTUNENA (1987), this is a necessity allowing the trees to maintain water balance since older needles show greater cuticular and stomatal transpiration. Due to defoliation, crowns of some pine trees growing in the vicinity of the cement plant are markedly opened. Openness 


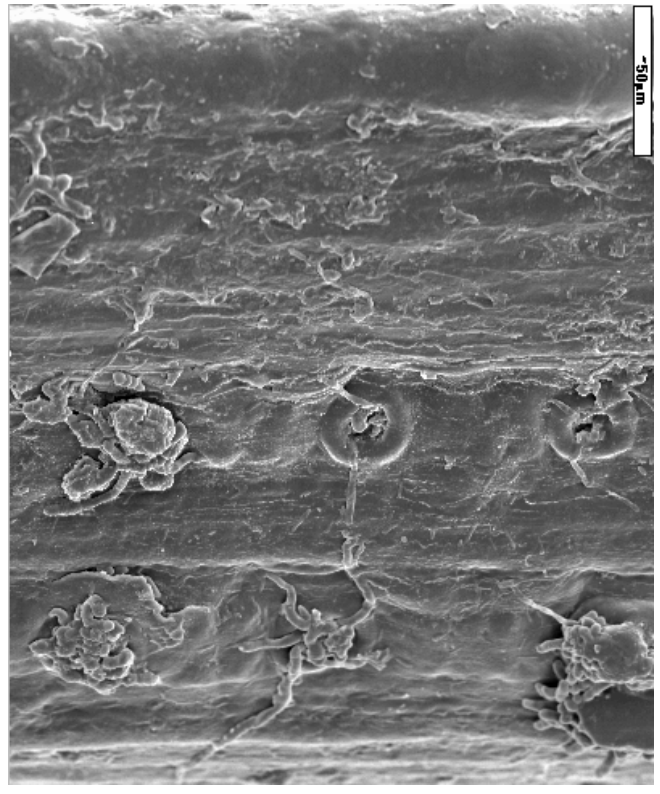

Photo 1. Wax layer of 2-year-old pine needle, Ożarów area (500x).

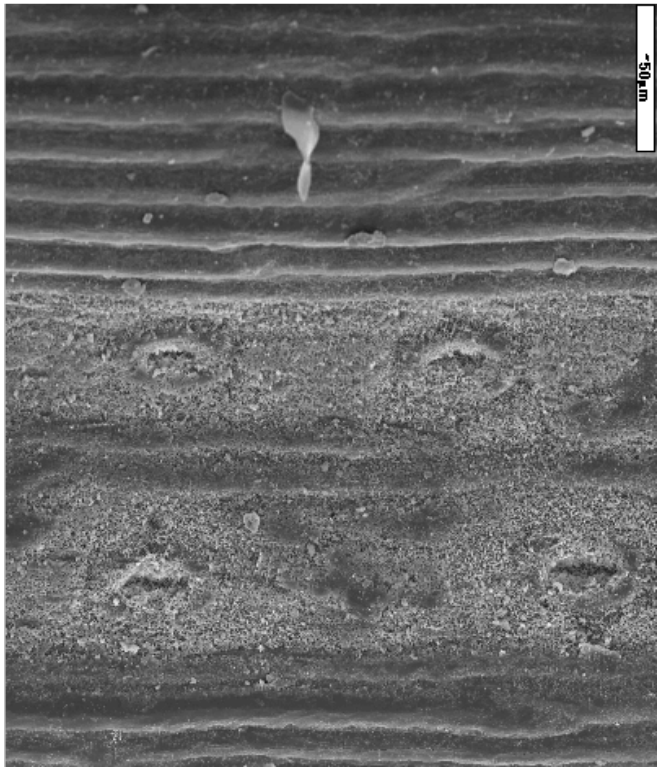

Photo 3. Wax layer of 2-year-old pine needle, Wymysłów area (500x).

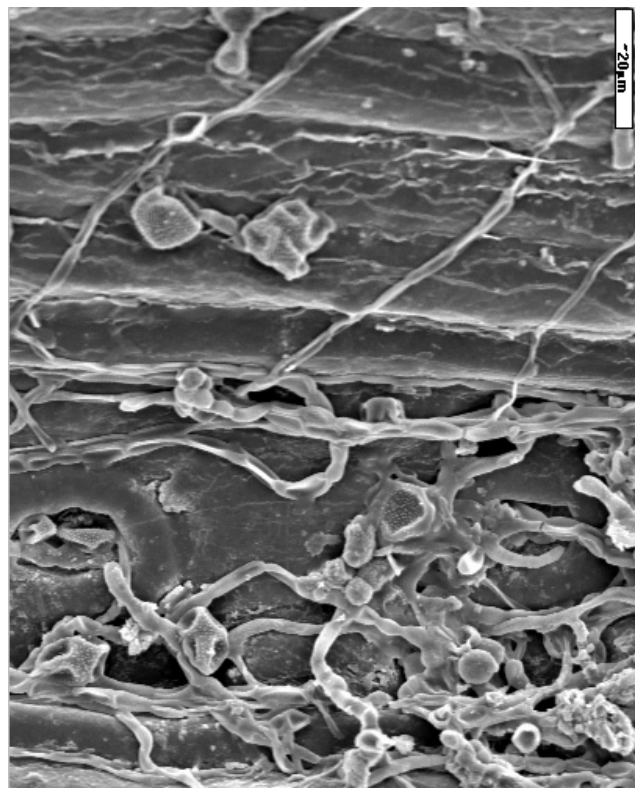

Photo 2. Wax layer of 2-year-old pine needle, Ożarów area (1000x).

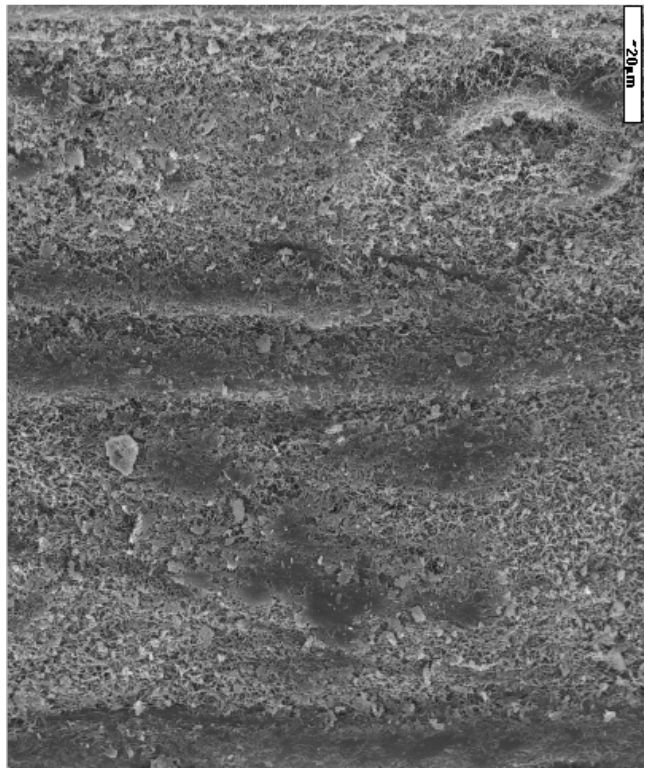

Photo 4. Wax layer of 2-year-old pine needle, Wymysłów area (1000x).

type can be classified as arch-shaped or bottom-up type (LESIŃSKI et al. 1992). SEM image analysis confirmed that wax network structure of pine needles collected from Wymysłów (control area) was well-preserved (Photo 3 and 4). Their crowns were dense with complete needle foliage retained. 
The study presented particulate pollutants deposited on needle surface can cause erosion of the wax structure (GRILL, GOLOB 1983) and clog the surface structures, impairs intensity of gas absorption, decreases intensity of light reaching the surface, thereby limiting intensity of photosynthesis even by up to $30 \%$ (AUCLAIR 1977; LARILAND et al. 1978; GRESZTA et al. 2002). The natural process of stomata filling with a network of wax fibers begins in the second year of needle life, then it gradually undergoes erosion that lasts up to 4-6 years (TURUNEN, HUTTUNEN 1990). Anthropogenic factors including particulate air pollution greatly accelerate wax structure degradation leading to complete decay of stomata filling with crystalline wax network. This process was used by TURUNENA et al. (1992) to develop the method of epicuticular wax assessment. Wax structure was scored according to the 6-point scale: class 0 (undeveloped wax structure), class I (100\% stomatal wax cover) class II (71-100\% stomatal wax cover), class III (31-70\% stomatal wax cover), class IV (0-30\% stomatal wax cover) and class V (0\% stomatal wax cover).

\subsection{Pine tree: total contents of selected elements in needles}

Chemical analysis of needles aimed to evaluate nutritional status of trees. Heavy metal contents were determined to assess degree and range of environmental load with industrial emissions. Mean contents of the elements under study in needles collected at study sites varied in a wide range, depending on sampling site and needle age (Tab. 1). Mean calcium contents showed the greatest variability. Calcium ions are stored in older organs and their contents strongly depend on the concentration in soil. The highest Ca contents in two-year-old pine needles were observed at the Sitkówka study site (mean $10350 \mathrm{mg} / \mathrm{kg} \mathrm{d.w.)} \mathrm{which} \mathrm{has} \mathrm{been} \mathrm{the}$ longest and the strongest exposed to alkalization. The Ca contents there were 2.5 times higher in comparison with the control site (Wymysłów). Pine needles from alkalized habitats contained also elevated potassium contents and increased concentrations of some heavy metals: copper, lead (3-fold) and strontium. In contrast, contents of several elements: were markedly decreased in needles from 
habitats remaining under pressure of cement and lime industry: Al, Fe (2-fold on average) and Mn (even 10-fold in two-year-old needles; Tab.1).

Lead content in one-year-old needles from the Sitkówka site fluctuating between 21 do $42.5 \mathrm{mg} / \mathrm{kg}$ (mean: $29.5 \mathrm{mg} / \mathrm{kg}$ ) were particularly alarming. Although lead does not play any physiological role in plants, it can slow down metabolic processes, especially when its content oscillates within toxic range for plants, i.e. 30 $\mathrm{mg} / \mathrm{kg}$ (KabAta-Pendias, Pendias 1999).

Values of $\mathrm{pH}$ in pine needles measured in $\mathrm{H} 2 \mathrm{O}$ and $\mathrm{KCl}$ (median, Tab.1) were elevated at alkalized sites in comparison with the control site. It can be assumed that $\mathrm{pH}$ of the needles, like bark, is a good indicator of habitat alkalization (SPOREK 1995; KUPČINSKIENE 2001; ŚWIERCZ 2005b).

\subsection{Transformation of forest community - species dynamics}

Transformations of species composition of studied forest communities induced by alkalization were investigated in three periods. All studied communities belonged to Dicrano-Pinion alliance, represented fresh coniferous forests growing on podsolic soils and rusty podsolic soils formed on loose to weakly clayey Pleistocene sands. Forty to seventy years old pine trees were the main component of these communities (mean 60 years old). Cover of tree layer did not significantly change throughout the study period $1990-2008$ and amounted to $60 \%$. Cover of the understory showed greater fluctuations and was slightly lower at alkalized sites (from $36 \%$ at the Ożarów site to $28 \%$ at the Małogoszcz site), while for the control site in Wymysłów it stabilized at 20 \% (Fig. 2). Shrub layer at the transformed sites was composed of pine saplings, Juniperus communis, Rhamnus catharticus, Frangula alnus. In the study period, the contribution of the taxa Sorbus aucuparia, Quercus robur, Frangula alnus increased slightly while that of Quercus petraea, Juniperus communis, Rhamnus catharticus decreased. No significant changes in the layer B have been identified on the comparative surface. 


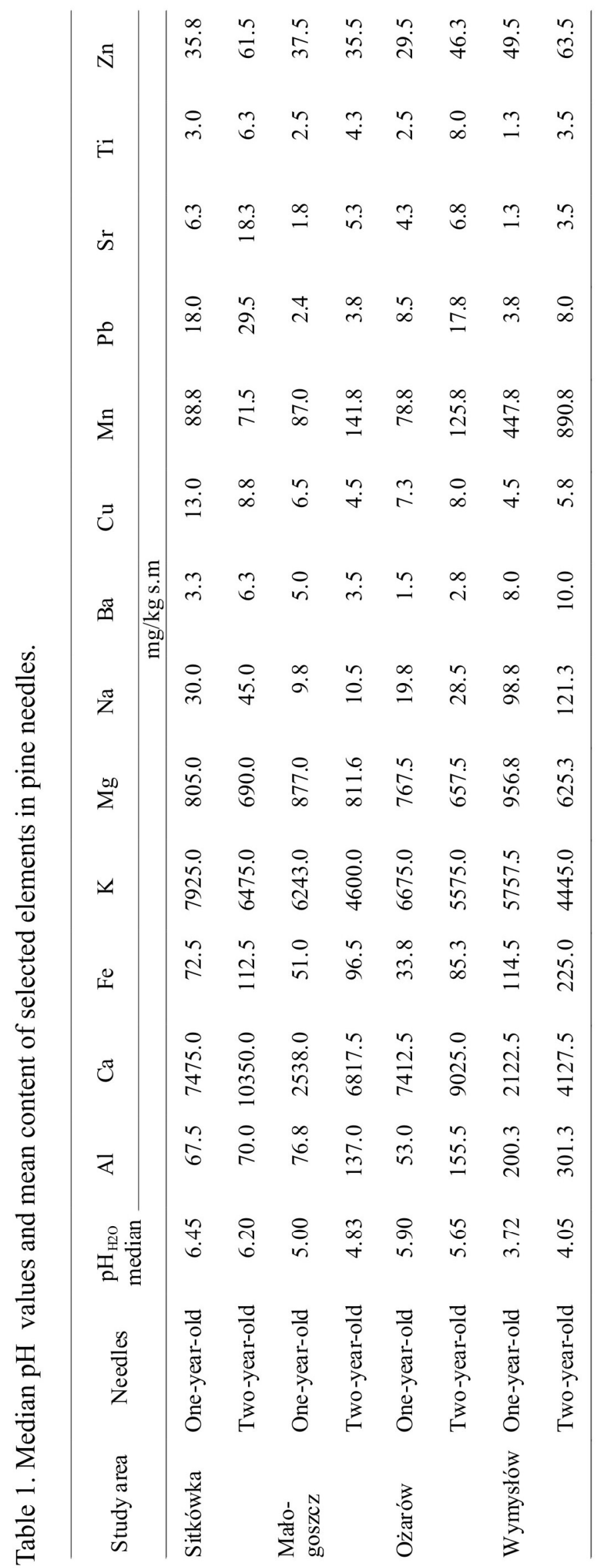




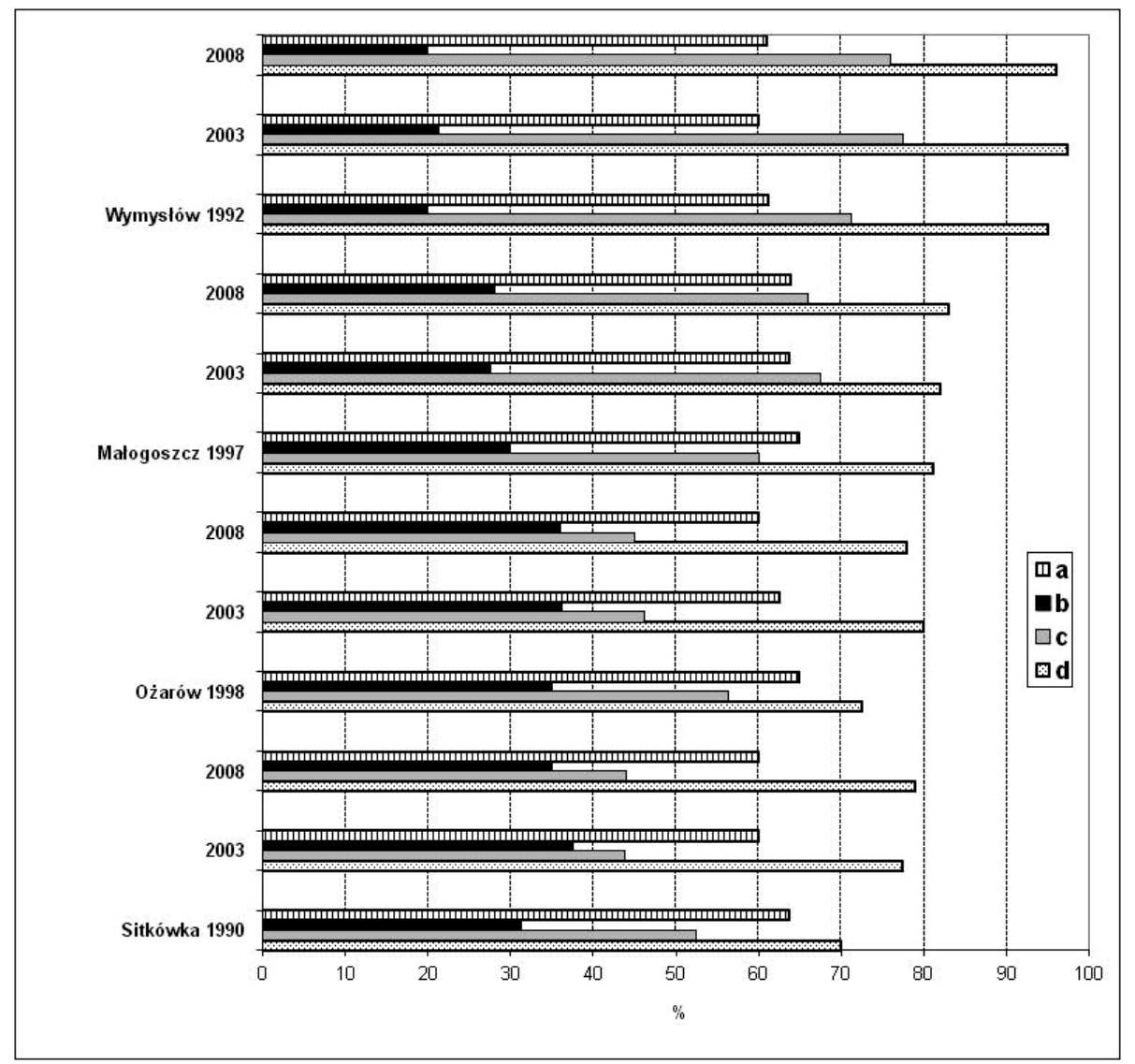

Fig. 2. Layer structure of forest communities in the study area. a - trees, b-shrubs, $\mathrm{c}-$ herbaceous plants, $\mathrm{d}-$ mosses.

The number of species and species diversity were the highest at the Sitkówka site where in total 150 species were identified (58 per relevé on average) in 1990. The number of species showed a regressive tendency when alkaline dust emission to soil decreased. In 2008, the total number of species was 122 (52 species per relevé on average). Similar tendency was observed at the Ożarów and Małogoszcz sites (Fig. 3). The number of species at control site totaled 40, and the mean ranged from 17 to 29 species per relevé (what is the typical phenomenon for pine forest MATUSZKIEWICZ and MATUSZKIEWICZ 1973) This value did not significantly change within study period from 1993 to 2008 ( \pm 2 species). 


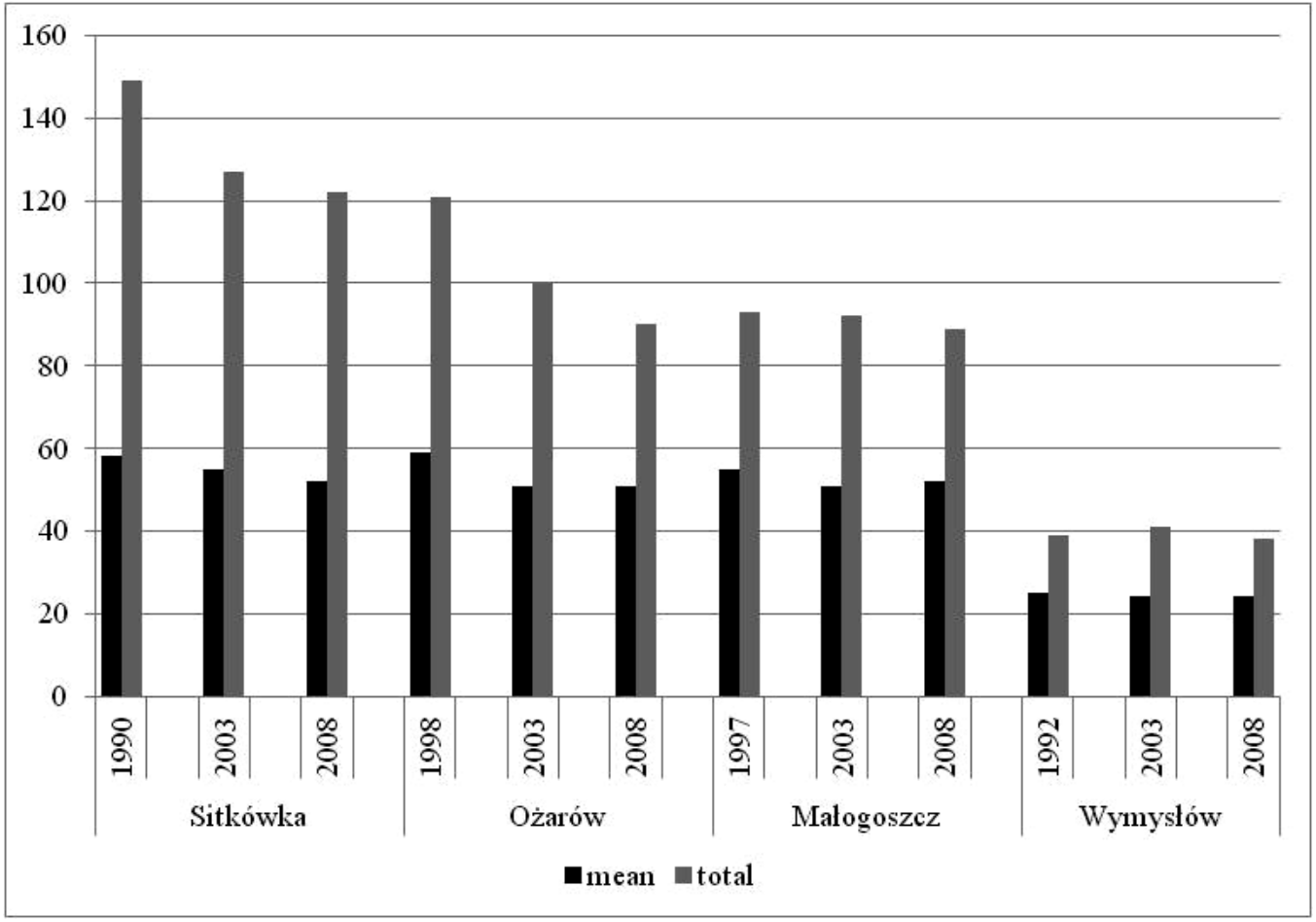

Fig. 3. Changess in the number of species in the studied sites.

A majority of species (from $40 \%$ to $62 \%$ ) occurring at sites under alkaline pressure were characterized by low constancy values. A small number of species (from $7 \%$ to $9 \%$ ) with the highest constancy (group V) indicates labile structure of the community. The contribution of species belonging to the highest constancy groups increased slightly in the period 1990-2008 (Fig. 4). Out of high-constancy species, Vaccinio-Piceetea class was represented only by Orthilia secunda, besides pine tree, Querco-Fagetea - Epipactis helleborine, Sedo-Scleranthetea - Festuca ovina and Hieracium pilosella, Epilobietea angustifolii association - Fragaria vesca, while a very abundant group of accompanying species contained Solidago virgaurea and Epipactis atrorubens.

Species composition of the communities under analysis did not allow for their precise syntaxonomic classification. The communities were exceptionally rich. Anthropogenic communities having developed in fresh coniferous forest habitats, producing degenerative forms of pine forests of Dicrano-Pinion alliance. 


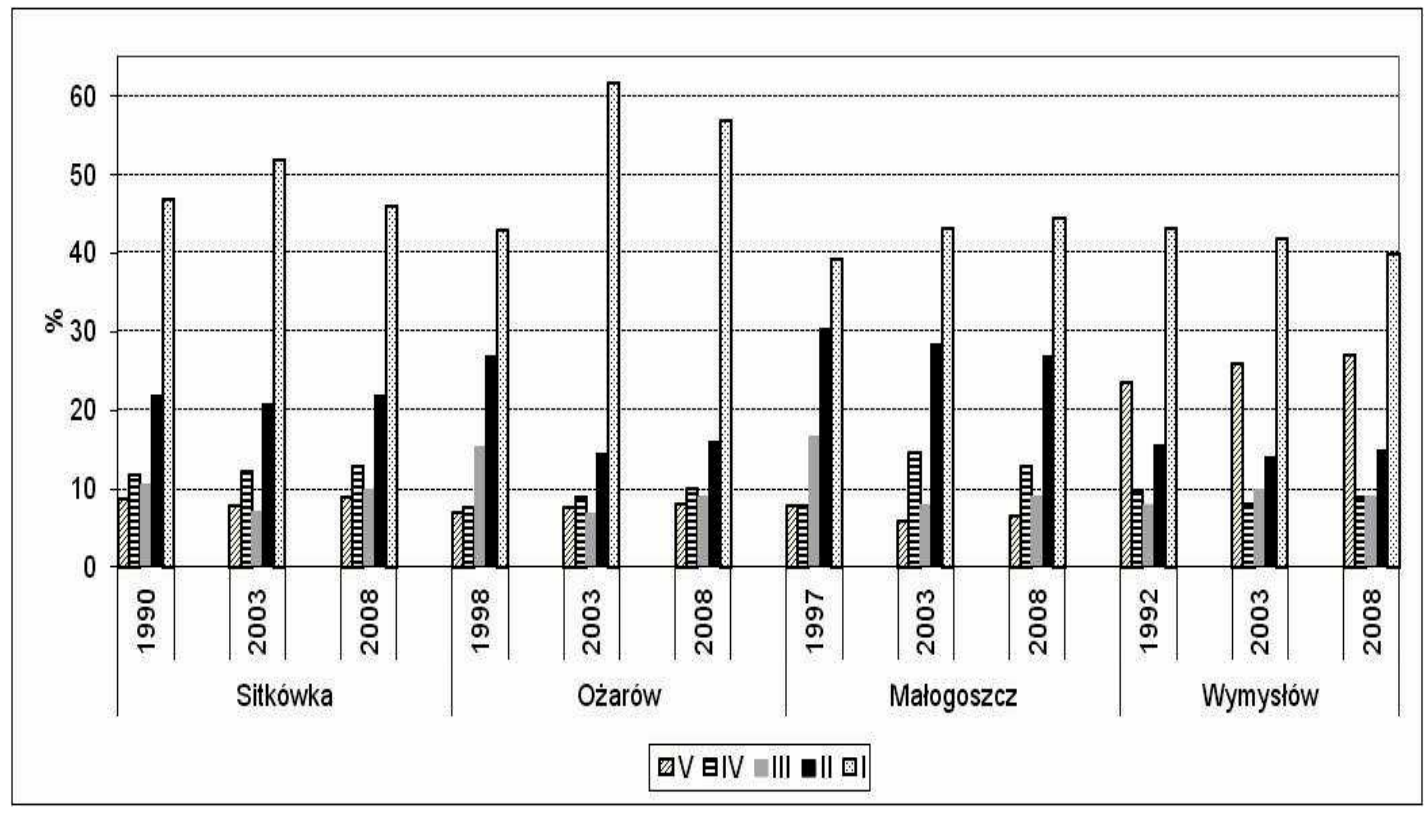

Fig. 4. Share of constancy clasess in forest communities in studies sites.

At the beginning of studies, the species number and diversity of the communities showed a relationship with increasing deposition of alkalizing compounds. It was associated with the apparent richness of habitat. Since 1990s, the number of taxa has declined with progressing habitat regeneration. Systematic values and mean constancy of the distinguished species groups indicated that none of these groups dominated in the structure of communities exposed to alkaline deposition (Tab. 2).

Systematic value of the species group characteristic of Vaccinio-Piceetea class growing at alkalized sites was low. It amounted to from 4.0 (Ożarów site) to 4.4 (Sitkówka site) in the period 1989 - 1990. In 2008, the systematic value for this species group was higher and ranged from 6.4 to 8.4. This is the result of a considerable lower imission of cement and lime dust to soil and opportunity for coniferous forest species to slowly return to presently more acidic habitats. Over the period 1992 - 2008, systematic value for species characteristic of Vaccinio-Piceetea classat the control site in Wymysłów changed negligibly from 33.2 to 31.4. 
Table 2. Synthetic values for phytosociological groups in the study area. Explanations: $\mathrm{z}$ - number of species, D (\%) - systematic values, G (\%) - total percentage of group of species, $\mathrm{S}(\%)$ - mean of group of species.

\begin{tabular}{|c|c|c|c|c|c|c|c|c|c|c|c|c|}
\hline \multirow[b]{2}{*}{ 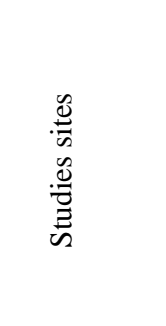 } & \multirow[b]{2}{*}{ 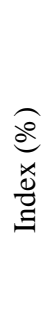 } & \multicolumn{11}{|c|}{ Group of species (Ch. Cl.) } \\
\hline & & 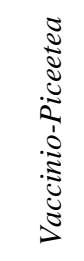 & 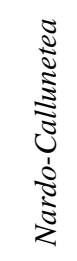 & 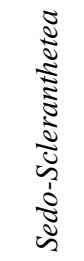 & 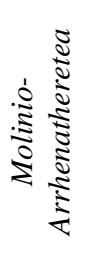 & 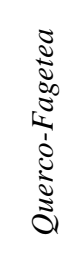 & 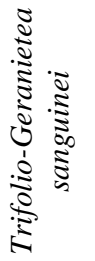 & 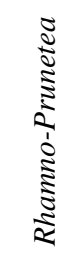 & 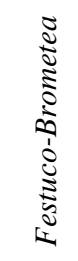 & 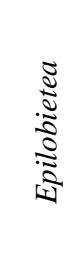 & 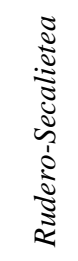 & 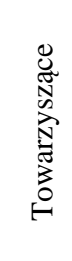 \\
\hline Sitkówka & $\mathrm{z}$ & 12 & 6 & 7 & 23 & 15 & 8 & 10 & 18 & 4 & 7 & 40 \\
\hline \multirow[t]{3}{*}{1989} & $\mathrm{D}$ & 4.4 & 0.5 & 2.5 & 3.6 & 1.6 & 1.2 & 3.3 & 3.6 & 1.8 & 0.6 & 8.0 \\
\hline & $S$ & 44.8 & 20.8 & 44.6 & 29.3 & 24.2 & 28.1 & 42.5 & 33.3 & 50.0 & 21.4 & 33.7 \\
\hline & $\mathrm{G}$ & 9.8 & 2.3 & 5.7 & 12.3 & 6.6 & 4.1 & 7.7 & 10.9 & 3.6 & 2.7 & 23.9 \\
\hline Sitkówka & $\mathrm{z}$ & 10 & 3 & 7 & 24 & 15 & 11 & 9 & 14 & 4 & 3 & 27 \\
\hline \multirow[t]{3}{*}{2003} & $\mathrm{D}$ & 5.6 & 0.2 & 2.9 & 4.2 & 2.2 & 1.0 & 5.1 & 3.6 & 2.2 & 0.4 & 8.0 \\
\hline & $S$ & 53.8 & 16.7 & 46.4 & 30.2 & 27.5 & 21.6 & 54.2 & 36.6 & 53.1 & 25.0 & 39.4 \\
\hline & G & 10.3 & 1.0 & 6.3 & 13.9 & 7.9 & 4.6 & 9.4 & 9.9 & 4.1 & 1.4 & 20.4 \\
\hline Sitkówka & $\mathrm{z}$ & 11 & 3 & 6 & 23 & 14 & 10 & 8 & 15 & 4 & 3 & 25 \\
\hline \multirow[t]{3}{*}{2008} & $\mathrm{D}$ & 6.4 & 0.3 & 2.9 & 4.2 & 2.1 & 0.8 & 4.7 & 3.1 & 1.7 & 0.4 & 9.3 \\
\hline & $S$ & 54.6 & 20.8 & 50.0 & 30.4 & 32.7 & 20.0 & 54.7 & 32.5 & 46.9 & 25.0 & 43.5 \\
\hline & G & 11.7 & 1.2 & 5.9 & 13.7 & 7.6 & 3.9 & 8.6 & 9.5 & 3.7 & 1.5 & 21.3 \\
\hline Ożarów & $\mathrm{z}$ & 11 & 4 & 8 & 22 & 12 & 8 & 9 & 10 & 4 & 8 & 25 \\
\hline \multirow[t]{3}{*}{1998} & D & 4.0 & 0.3 & 4.3 & 4.1 & 1.6 & 0.5 & 1.9 & 1.3 & 2.6 & 2.0 & 8.6 \\
\hline & S & 39.8 & 18.8 & 48.4 & 28.4 & 24.0 & 15.6 & 30.6 & 23.8 & 53.1 & 32.8 & 38.5 \\
\hline & G & 10.1 & 1.7 & 9.0 & 14.5 & 6.6 & 2.9 & 6.4 & 5.5 & 4.9 & 6.1 & 22.3 \\
\hline Ożarów & $\mathrm{z}$ & 12 & 1 & 5 & 18 & 10 & 3 & 8 & 6 & 4 & 7 & 26 \\
\hline \multirow[t]{3}{*}{2003} & D & 5.9 & 0.1 & 3.7 & 3.3 & 2.0 & 0.3 & 2.3 & 0.6 & 4.7 & 3.4 & 8.3 \\
\hline & $S$ & 44.8 & 12.5 & 55.0 & 27.1 & 28.8 & 20.8 & 34.4 & 20.8 & 68.8 & 44.6 & 36.1 \\
\hline & G & 13.2 & 0.3 & 6.8 & 12.0 & 7.1 & 1.5 & 6.8 & 3.1 & 6.8 & 7.7 & 23.1 \\
\hline Ożarów & $\mathrm{z}$ & 13 & 2 & 5 & 16 & 8 & 3 & 7 & 5 & 3 & 5 & 22 \\
\hline \multirow[t]{3}{*}{2008} & D & 8.4 & 0.1 & 4.6 & 3.1 & 2.9 & 0.2 & 2.3 & 0.7 & 5.9 & 3.9 & 8.9 \\
\hline & $S$ & 50.0 & 12.5 & 60.0 & 27.3 & 37.5 & 16.7 & 35.7 & 22.5 & 87.5 & 55.0 & 39.8 \\
\hline & G & 16.7 & 0.6 & 7.7 & 11.3 & 7.7 & 1.3 & 6.4 & 2.9 & 6.8 & 7.1 & 22.5 \\
\hline Małogoszcz & $\mathrm{z}$ & 12 & 4 & 5 & 15 & 15 & 5 & 6 & 5 & 3 & 6 & 17 \\
\hline \multirow[t]{3}{*}{1997} & $\mathrm{D}$ & 4.2 & 0.9 & 3.8 & 4.1 & 2.9 & 0.4 & 0.9 & 0.9 & 3.2 & 2.3 & 8.5 \\
\hline & $S$ & 35.4 & 28.1 & 52.5 & 31.7 & 26.7 & 17.5 & 22.9 & 25.0 & 62.5 & 37.5 & 42.6 \\
\hline & $\mathrm{G}$ & 11.7 & 3.1 & 7.2 & 13.1 & 11.0 & 2.4 & 3.8 & 3.4 & 5.2 & 6.2 & 20.0 \\
\hline Małogoszcz & $\mathrm{z}$ & 13 & 4 & 4 & 19 & 10 & 3 & 6 & 4 & 3 & 8 & 18 \\
\hline 2003 & $\mathrm{D}$ & 8.4 & 1.3 & 3.6 & 2.2 & 3.4 & 0.2 & 0.7 & 0.7 & 2.9 & 2.0 & 6.8 \\
\hline
\end{tabular}


Table 2. (Continued)

\begin{tabular}{|c|c|c|c|c|c|c|c|c|c|c|c|c|}
\hline \multirow[b]{3}{*}{ Małogoszcz } & $\mathrm{S}$ & 48.1 & 34.4 & 56.3 & 20.4 & 35.0 & 16.7 & 20.8 & 25.0 & 58.3 & 29.7 & 36.8 \\
\hline & G & 17.5 & 3.9 & 6.3 & 10.9 & 9.8 & 1.4 & 3.5 & 2.8 & 4.9 & 6.7 & 18.6 \\
\hline & $\mathrm{z}$ & 15 & 4 & 4 & 17 & 11 & 3 & 5 & 4 & 3 & 7 & 16 \\
\hline \multirow[t]{3}{*}{2008} & $\mathrm{D}$ & 8.4 & 1.9 & 3.9 & 2.0 & 2.3 & 0.3 & 0.7 & 0.9 & 1.7 & 1.6 & 6.5 \\
\hline & $S$ & 45.0 & 40.7 & 59.4 & 20.6 & 27.3 & 16.7 & 22.5 & 28.1 & 45.8 & 28.6 & 38.3 \\
\hline & G & 18.6 & 4.5 & 6.5 & 9.6 & 8.3 & 1.4 & 3.1 & 3.1 & 3.8 & 5.5 & 16.9 \\
\hline Wymysłów & $\mathrm{z}$ & 18 & 4 & 6 & 6 & \multirow{4}{*}{ - } & \multirow{4}{*}{-} & \multirow{4}{*}{-} & \multirow{4}{*}{-} & \multirow{4}{*}{-} & \multirow{4}{*}{-} & 8 \\
\hline \multirow[t]{3}{*}{1992} & D & 33.2 & 5.5 & 2.3 & 1.9 & & & & & & & 2.7 \\
\hline & S & 65.3 & 56.3 & 41.7 & 27.1 & & & & & & & 28.1 \\
\hline & G & 50.8 & 9.7 & 5.4 & 7.0 & & & & & & & 9.7 \\
\hline Wymysłów & $\mathrm{z}$ & 21 & 3 & 3 & 5 & \multirow{4}{*}{-} & \multirow{4}{*}{ - } & \multirow{4}{*}{ - } & \multirow{4}{*}{ - } & \multirow{4}{*}{ - } & \multirow{4}{*}{-} & 5 \\
\hline \multirow[t]{3}{*}{2003} & $\mathrm{D}$ & 32.5 & 7.3 & 2.2 & 1.6 & & & & & & & 3.4 \\
\hline & $S$ & 59.5 & 75.0 & 41.7 & 27.5 & & & & & & & 40.0 \\
\hline & G & 53.8 & 9.7 & 5.4 & 5.9 & & & & & & & 8.6 \\
\hline Wymysłów & $\mathrm{z}$ & 22 & 4 & 3 & 5 & \multirow{4}{*}{-} & \multirow{4}{*}{ - } & \multirow{4}{*}{-} & \multirow{4}{*}{-} & \multirow{4}{*}{-} & \multirow{4}{*}{-} & 5 \\
\hline \multirow[t]{3}{*}{2008} & D & 31.4 & 8.0 & 1.8 & 1.6 & & & & & & & 3.8 \\
\hline & S & 58.0 & 79.1 & 37.5 & 27.5 & & & & & & & 42.5 \\
\hline & G & 54.3 & 10.1 & 4.8 & 5.9 & & & & & & & 9.0 \\
\hline
\end{tabular}

Species characteristic of Nardo-Callunetea class almost completely vanished (D value ranged from 0.1 to 1.3). Only species like Carex pilulifera, Luzula multiflora, Viola canina having low constancy values were able to exist in extremely disadvantageous conditions for this group. A slight increase in species belonging to this class (expressed by the sum of coverage) was noted in the study period only at the Małogoszcz site. Among species distinguishing of Querco-Fagetea class, Epipactis helleborine, Viola reichenbachiana, Geum urbanum dominated. A slight progression of Querco-Fagetea classes, and a decreased number of species of Trifolio-Geranietea sanguinei and Festuco-Brometea classes was observed at the Sitkówka site over 18-year observation period and at the Ożarów site over 10 years. The contribution of the species Epipactis helleborine, Orthilia secunda, Fragaria vesca, Torilis japonica and a bryophyte Hylocomnium splendens slightly increased in the phytocenoses under analysis in alkalized habitats. In spite of more favourable habitat conditions at the Sitkówka site, Vaccinum myrlillus and V. vitis-idaea were not found. Bilberries occurred only at the Małogoszcz site, the least transformed by alkaline deposition (lingonberries were encountered only sporadically). The 
physicochemical proprieties of soils changed radically. Arose new conditions not favourable for acidophilic pine forest vegetation.

Analysis of mean indicator values for full species composition of the communities under study occurring at alkalized sites confirmed elevated significance of species characterized by greater environmental requirements for light, acidity and temperature and lower requirements for humidity and organic matter content in soil (Fig. 5). Along with the decrease of alkaline deposition to soil, the contribution of thermophilous species preferring full light and higher soil $\mathrm{pH}$ values.

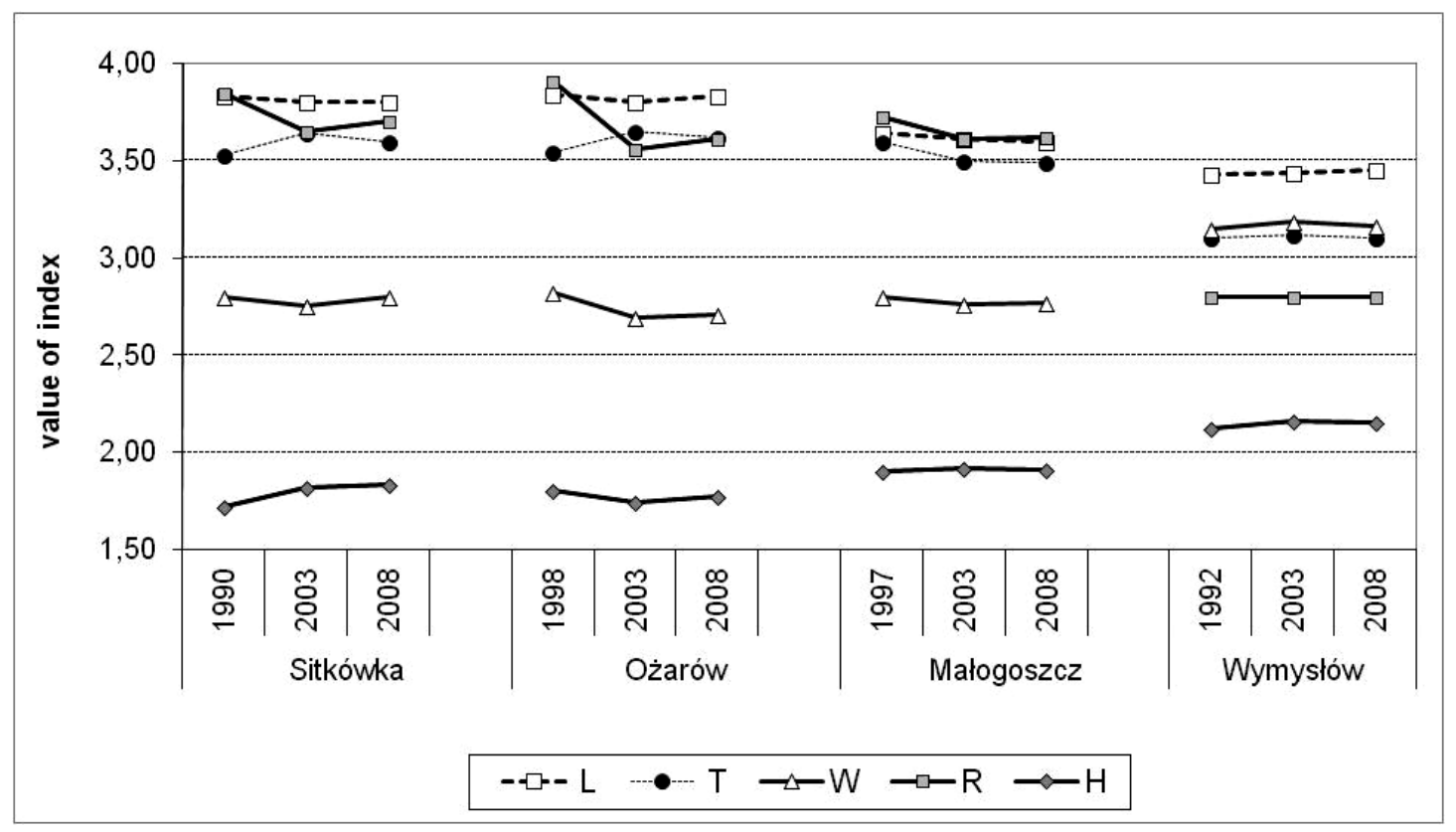

Fig. 5. Changes in mean values of ecological indices in 1989-2008 in studies forests. $\mathrm{L}$ - light, $\mathrm{T}$ - temperature, $\mathrm{R}$ - reaction, $\mathrm{H}$ - humus, $\mathrm{W}$ - moisture.

Anthropogenically transformed habitats can be a dwelling place for many rare and endangered taxa (Box 1999). Study sites modified by imission of cement and lime dust were found to be the habitat of 8 herbaceous species under strict protection: Chimaphilla umbellata, Epipactis helleborine, Epipactis atrorubens, Goodyera repens, Cephalanthera longifolia, Platanthera bifolia, Anemone sylvestris, Campanula sibirica and 3 species under partial protection: Frangula 
alnus, Viburnum opulus, Primula veris. Coniferous forest vegetation developing in alkalized habitats over the last 18 years at the Sitkówka site and 10 years at the Małogoszcz and Ożarów sites have undergone significant transformations.

The present communities state is the effect of "an unintended experiment" (FALIŃSKI 2001) provoked by human activity. The first period of exposure of the forest communities under study to cement and lime industry emission was distinguished by conspicuous explosion of biodiversity caused by intromission of marginal and meadow species ecologically alien not only to coniferous forests but also to forests in general (ŚWIERCZ 2005a) and by regression of species preferring acidic, shady, humid habitats rich in organic matter. Species diversity and specific species composition of phytocenoses under study developed under strong anthropopressure and exploitation of coniferous forests in the past. Thus, human activity overlain on natural diversity of communities can contribute either to greater heterogeneity of forest communities (ŁASKA 1996) or reduced biodiversity (Christiansen, EMBorg 1996; NiENARTOWiCz et al. 2001). Set out results show that the biological variety grew up markedly under the influence of alkalization on studies areas.

In parallel with the declining alkaline deposition, species composition slowly stabilizes and still barely noticeable regenerative tendency appears which consists in progression of some acidophilic species (Trientalis europaea, Calluna vulgaris) and regression of some calciphilous species, like Trifolium alpestre, Agrimonia eupatoria, Coronilla varia. No new species were identified in the communities under study in 2008.

Long-term and directed vegetation transformations are superimposed on fluctuations induced by variable often difficult to define causes. They may be provoked by weather conditions, particularly water availability, fluctuations in species biology and habitat conditions (BAKER 1990; SOLON, ROO-ZIELIŃSKA 2001; FALIŃSKI 2001). Species diversity in forest communities is also increased by general environmental factors, like the presence of diaspore sources (DzWONKO, GAWROŃSKI 1994; NIENARTOWICZ et al. 2001). All studied phytocenoses (except Wymysłów site) are located in the vicinity of human residential quarters and farms 
which also facilitates penetration of alien species, e.g. from fields, and trampling or bringing new species.

\section{CONCLUSIONS}

- Reduced cement and lime deposition in soil has the strongest effect on the state of pine assimilatory organs and species composition of forest communities developing under alkaline pressure.

- Older pine needles having accumulated higher heavy metal contents are more useful as indicators for environmental studies.

- There were essential differences in the accumulation of elements in pine needles collected at alkalized sites in comparison with needles from the control site.

- SEM analysis of morphological features of pine needle surface, in particular degree of preservation of epicuticular waxes can be helpful as an indicator of assimilatory organ degeneration caused by dust deposition which induces wax layer erosion.

- Other noticeable processes include slow regenerative changes of the community with a tendency towards an increase in the contribution of acidophilic coniferous forest species with lower light and temperature requirements and suppression of penetration of meadow, ruderal and associated taxa. Further studies are required in order to define succession rate and direction and tendency of changes in species composition of these communities.

\section{REFERENCES}

AUClaIR, D. 1977. Effects of dusts on photosynthesis. II. Effects of particulate matter on photosynthesis of Scots pine and poplar. Amer. Sci. For. 34: 47-58.

BAČı́́, T., Lynch, A.H., Cutler, D. 1999. Reactions to cement factory dust contamination by Pinus halepensis needles. Env. Exp. Botany. 41 (2): 155-166.

BAKER, W.L. 1990. Species richness of Colorado riparian vegetation. J. Veg. Sci. 1: $119-124$.

BoX, J. 1999. Nature conservation and post-industrial landscape. Industry. Arch. Rev. 21 (2): 38-146. 
Christiansen, M., EMborg, J. 1996. Biodiversity in natural versus managed forest in Denmark. For. Ecol. Manage. 85: 47-51.

DZWOnKO, Z., GAWROŃSKI, S. 1994. The role of woodlands fragments, soil types, and dominant species in secondary succesion on the western Carpathian foothills. Vegetatio 111: 149-160.

EAgER, C., AdAms, M.B. (eds). 1992. Ecology and decline of Red spruce in the Eastern united States. Springer - Verlag, Berlin - Heildelberg.

GRILL, D., GolOB, P. 1983. SEM-investigations of different dust deposition on the surface of coniferous needles and the efect on the needle wax. Aquilo Ser. Bot., 19: $255-261$.

Greszta, J., GruszKa, A., Kowalkowska, M. 2002. Wpływ imisji na ekosystem. Śląskie Wydawnictwo Naukowe, Katowice.

FALIŃSKI, J.B. 2001. Przewodnik do długoterminowych badań ekologicznych. Wydawnictwo Naukowe PWN, Warszawa.

Kabata-Pendias, A., Pendias, H. 1999. Biogeochemia pierwiastków śladowych. Wydawnictwo Naukowe PWN, Warszawa.

KUPČINSKIENE, E. 2001. Pinus sylvestris needle surface characteristics in alkalised environmental. Biologija 2: 25-27.

Lariland, N., Lovelius, N.B, Yatschenko-Khmelevskit, A.A. 1978. The effect of dust pollution from cement factories on growth of oak. Bot. Zh. 63: 721-729.

Lesiński, J.A, DMYTERKo, E., GrZYB, M. 1992. Skandynawska metoda oceny uszkodzeń sosny i świerka. Sylwan 6: 19-31.

ŁASKA, G. 1996. Klasyfikacja form degeneracji zbiorowisk gradowych w Puszczy Knyszyńskiej. Zesz. Nauk. Politechniki Bialostockiej, Nauki Techn. 105: Inżynieria Środowiska 8: 5-87.

Matuszkiewicz, W., MatuszkiewiCZ, J.M. 1973. Przegląd fitosocjologiczny zbiorowisk Polski. Cz. 2. Bory sosnowe. Phytocenosis 2 (4): 273-356.

MÄKelä, A., HutTunena, S. 1987. Cuticular needle erosion and winter drought in poluted environments - a model analysis. Working paper of the International Institute for Applied Systems Analysis, Laxenburg, Austria. 
Nienartowicz, A., Cyzman, W., Kunz, M., DeptuŁA, M. 2001. Różnorodność gatunkowa lasów naturalnych i odtworzonych na gruntach porolnych. Prace Geogr. 179: 51-68.

PAWŁOWSKI, B. 1977. Skład i budowa zbiorowiska roślinnych oraz metody ich badania. In: W. SzAFER, K. ZARZYCKI K. (eds), Szata roślinna Polski, T.I, PWN, Warszawa, pp. 237-268.

SolON, J., RoO-ZIELIŃSKA, E. 2001. Bogactwo gatunkowe zbiorowisk roślinnych w okolicach Pińczowa a ich wymagania ekologiczne. Prace Geogr. 179: 209-225.

SPOREK, K. 1995. Odczyn kory sosny zwyczajnej (Pinus sylvestris L.) wskaźnikiem zanieczyszczeń atmosfery pyłami alkalicznymi. Sylwan 9: 97-104.

STASZEWSKI, T. 2004. Reakcja drzewostanów świerkowych na depozycję zanieczyszczeń powietrza. Wydawnictwo Uniwersytetu Śląskiego, Katowice, pp. $1-150$.

ŚwIERCZ, A. 2005 a. Analiza procesów glebowych i przekształceń roślinnych w zalkalizowanych siedliskach leśnych regionu świętokrzyskiego. Kom. ”Człowiek i Środowisko" PAN, Zesz. Nauk 39, Warszawa - Kielce.

ŚWIERCZ, A. 2005 b. Wykorzystanie kory sosny zwyczajnej do oceny zanieczyszczeń pyłami cementowo-wapienniczymi w województwie świętokrzyskim. Sylwan 4: 34-40.

Turunen, M., HutTunen, S. 1990. A review of response of epicuticular wax of conifer needles to air pollution. J. Environ. Qual. 19: 35-45.

Turunen, M., Huttunen, S., Back, J., Koponen, J., Huhtala, P. 1992. Needle damage Scots pine of Lapland and Kola Peninsula. In: E. TIKkANEN, M. VARMOla, T. KatermaA. (eds), Symposium on the state of the environment and environmental monitoring in northern Fennoscandia and the Kola Peninsula, 6-8 October 1992, Arctic Centre Publications 4, pp.235-239.

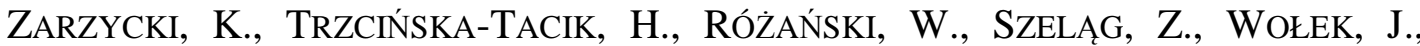
KORZENIAK, U. 2002. Ecological indicator values of vascular plants of Poland. W. Szafer Institute of Botany, Polish Academy of Sciences. Kraków. 